\title{
PENGEMBANGAN MODUL BAHASA INDONESIA BERMUATAN NILAI KARAKTER KEBANGSAAN BAGI MAHASISWA PGSD
}

\author{
Tabah Subekti'), Ela Minchah Laila Alawiyah' ${ }^{2)}$, dan Sumarlam ${ }^{3)}$ \\ ${ }^{1}$ Program Studi S3 PBI Pascasarjana UNS; ${ }^{2}$ FKIP, Universitas Muhammadiyah Magelang; ${ }^{3}$ Pascasarjana \\ Universitas Sebelas Maret \\ ${ }^{1}$ tabahsubekti2@gmail.com; ${ }^{2}$ emlaa@yahoo.com; ${ }^{3}$ sumarlamwd@gmail.com
}

\begin{abstract}
The research aims to develop module of bahasa which combined by national character. Background of this study is there's not yet any module of bahasa which combined by national character, in the other side Indonesia needs teacher who able to teach and guide the children with national character to tighten the children's nationality. By using this product, we hope that the student of elementary school teacher education (candidate of teacher) will able to teach and guide the children with national character. The research was supported by the expert in each field. The research divided become four step which called four-D (1) define; (2) design; (3) develop; and (4) disseminate. But, the duration of the research is only one year, so it caused the research only able to achieve third level (develop). The product of this research is a module of bahasa combined by national character which ready to used by lecturer in elementary school teacher education. Object of the research are the student of elementary school teacher education (candidate of teacher) in University of Muhammadiyah Magelang, Central Java. The result of the study described that development of module bahasa is done effectively. It can be seen from the lecturers and students respond who had helped by the module.
\end{abstract}

Keywords: module, national character.

\section{PENDAHULUAN}

Penerapan kurikulum 2013 yang sudah dimulai sejak dua tahun terakhir ini, pernah akan tertunda dan terancam gagal dilaksanakan setelah diterbitkannya Surat Edaran Mendikbud Nomor: 179324/MPK/KR/2014 tgl 5 Desember 2014 tentang penghentian implementasi kurikulum 2013 dan penggunaan kembali kurikulum tahun 2006 (kurikulum KTSP). Mantan Menteri Pendidikan dan Kebudayaan Republik Indonesia, Anis Baswedan (2014: 2) menegaskan bahwa salah satu penyebab kegagalan /ketertundaan penerapan kurikulum 2013 ialah ketidak siapan Sumber Daya Manusia (SDM) terutama tenaga guru dalam menerapkan kurikulum 2013. Guru merupakan penerjemah kurikulum ke dalam pembelajaran di sekolah (Suryaman, 2012: 34) oleh karenanya ketidaksiapan guru sangat berpengaruh pada ketertundaan kurikulum 2013.

Fakta di lapangan menunjukkan bahwa pelatihan dan penataran guru yang terlalu mendadak dengan jangka waktu pelatihan yang sangat singkat/terbatas berdampak pada ketidaksiapan guru dalam menerapkan kurikulum 2013, sehingga pemerintah tidak dapat memenuhi kebutuhan SDM yang cakap dalam implementasi kurikulum 2013. Kegagalan penerapan kurikulum 2013 dapat diperparah lagi dengan banyaknya lulusan mahasiswa calon guru dari Perguruan Tinggi (baik negeri maupun swasta) yang ketika lulus kuliah ternyata belum memahami dan mampu menerapkan kurikulum 2013. Salah satu faktornya karena saat berkuliah mereka masih mendapatkan materi atau modul lama yang belum mengintegrasikan nilai-nilai karakter kebangsaan di dalamnya. Dengan demikian, 
maka lulusan (calon guru) yang dihasilkan oleh perguruan tinggi pencetak guru belum menguasai kurikulum 2013. Hal ini dapat mengakibatkan ketidaksesuaian antara kualitas lulusan dan tuntutan kerja.

Idealnya, perguruan tinggi pembentuk tenaga pendidik dan tenaga kependidikan harus menjalankan program yang sejalan dengan program pemerintah terutama dalam hal pelaksanaan kurikulum berbasis karakter saat ini. Hal ini sesuai dengan fungsi perguruan tinggi sebagai pembentuk watak serta peradaban bangsa yang bermartabat dalam rangka mencerdaskan kehidupan bangsa (Pasal 4a. UU no 12 tahun 2012 tentang pendidikan tinggi). Penyelarasan program perguruan tinggi dengan program pemerintah dapat dilakukan salah satunya dengan menerapkan metode perkuliahan yang dapat memberikan bekal pengetahuan mengenai konsep kurikulum 2013 terhadap mahasiswa calon guru secara mendalam. Dengan demikian lulusan mahasiswa calon pendidik dan tenaga kependidikan dipastikan mampu menerapkan konsep kurikulum 2013 dengan baik.

Banyak upaya yang dapat dilakukan Perguruan Tinggi pencetak tenaga pendidik dan tenaga kependidikan dalam menyambut pelaksanaan kurikulum 2013 jika mengacu pada pasal 4a UU nomer 12 tahun 2012 tersebut, beberapa di antaranya dari skala terluas, melalui: (1) koordinasi antarlembaga perguruan tinggi pencetak tenaga pendidik dan kependidikan; (2) himbauan oleh pimpinan perguruan tinggi kepada staf pengajar untuk mengemas perkuliahan sesuai dengan penerapan kurikulum saat ini; atau (3) inisiatif dosen untuk mengelola perkuliahan sesuai penerapan kurikulum yang berlaku saat ini. Inisiatif tersebut dapat berupa mengembangkan metode perkuliahan, mengembangkan modul, materi, dan media, yang selaras dengan kurikulum yang berlaku.

Berkaca pada beberapa hal tersebut, maka mengembangkan modul perkuliahan bahasa Indonesia bermuatan nilai-nilai karakter kebangsaan merupakan salah satu upaya menyiapkan pelaksanaan kurikulum 2013. Setelah mempelajari modul perkuliahan bermuatan karakter kebangsaan, mahasiswa diharapkan mampu mendapatkan bekal pemahaman kurikulum 2013 yang dikenal dengan kurikulum berbasis karakter, serta mampu mengaplikasikannya di sekolah. Dampak positif lainnya yaitu ketika pengembangan modul bermuatan nilai karakter ini menunjukkan peningkatan yang signifikan, maka dapat diupayakan untuk mengembangkan modul perkuliahan bermuatan nilai karakter kebangsaan pada mata kuliah lain selain bahasa Indonesia di perguruan tinggi seluruh Indonesia sehingga memperoleh dampak yang lebih luas. Kesiapan lulusan mahasiswa calon guru untuk melaksanakan kurikulum bermuatan karakter ini akan sangat mendukung pemantapan implementasi kurikulum 2013 pada masa mendatang, sehingga penerapan kurikulum 2013 tidak lagi mengalami ketertundaan/ kegagalan.

Luaran hasil penelitian ini berupa: (1) modul perkuliahan pendidikan bahasa Indonesia bermuatan nilai-nilai karakter kebangsaan (hard copy dan soft copy), (2) artikel ilmiah hasil penelitian pengembangan yang dipublikasikan melalui jurnal/prosiding, dan (3) lulusan mahasiswa (calon guru SD) yang mampu dan siap menerapkan kurikulum 2013 pada tahun-tahun mendatang. Adapun kontribusi hasil penelitian ini antara lain: (1) bagi pemerintah, dapat mendukung kesuksesan implementasi kurikulum 2013 yang saat itu masih mengalami ketertundaan; 
(2) bagi institusi pendidikan dasar dan menengah, dapat terpenuhinya kebutuhan tenaga pengajar yang mampu dan siap menerapkan kurikulum 2013; (3) bagi perguruan tinggi, dapat menyelenggarakan perkuliahan yang sesuai dengan tuntutan kurikulum yang berlaku saat ini melalui penyediaan modul yang bermuatan nilai karakter kebangsaan; (4) bagi mahasiswa calon guru, dapat meningkatkan kompetensi diri dalam rangka implementasi kurikulum 2013; dan (5) bagi peneliti, dapat meningkatkan profesionalisme kerja dan mengembangkan diri sesuai bidang keilmuan yang dimiliki.

Modul merupakan satuan program belajar mengajar yang terkecil, yang dipelajari oleh pembelajar secara mandiri (Winkel, 2009:472). Sementara itu menurut ahli lain, dikemukakan pula bahwa modul adalah bahan ajar yang disusun secara sistematis dan menarik yang mencakup isi materi, metode, dan evaluasi yang dapat digunakan secara mandiri untuk mencapai kompetensi yang diharapkan (Anwar, 2010:90). Senada dengan dua pendapat ahli tersebut, modul dapat pula diartikan sebagai suatu kesatuan bahan belajar yang disajikan dalam bentuk self- instruction, artinya bahan belajar yang disusun di dalam modul dapat dipelajari siswa secara mandiri dengan bantuan yang terbatas dari guru atau orang lain (Depdiknas, 2006: 132). Menurut Mulyasa dalam (Rusimamto, 2013: 47) modul adalah suatu proses pembelajaran mengenai suatu satuan bahasan tertentu yang disusun secara sistematis, operasional, dan terarah untuk digunakan oleh peserta didik, disertai dengan pedoman penggunaannya untuk para pengajar. Pengajaran modul merupakan usaha penyelenggaraan pengajaran individual yang memungkinkan pembelajar menguasai satu unit bahan pelajaran sebelum dia beralih kepada unit berikutnya. Berdasarkan beberapa pendapat para ahli di atas, maka dapat disimpulkan bahwa modul perkuliahan adalah salah satu bentuk bahan ajar yang dikemas secara sistematis dan menarik sehingga mudah untuk dipelajari oleh mahasiswa secara mandiri maupun klasikal dengan memperhatikan kemampuan individu pembelajar (mahasiswa).

Istilah karakter berarti sifat-sifat kejiwaan, akhlak atau budi pekerti yang membedakan seseorang dari yang lain. Sementara mengatakan bahwa karakter merupakan cara berpikir dan berperilaku yang menjadi ciri khas tiap individu untuk hidup dan bekerja sama, baik dalam lingkup keluarga, masyarakat, bangsa, maupun negara (Suyanto, 2010:74). Senada dengan dua pengertian tersebut dijelaskan pula bahwa karakter adalah ciri khas yang dimiliki oleh suatu benda atau individu (Kertajaya, 2010:3). Ciri khas tersebut adalah asli dan mengakar pada kepribadian benda atau individu tersebut, serta merupakan penggerak yang mendorong bagaimana seorang bertindak, bersikap, berucap, dan merespon sesuatu. Sementara itu pendidikan karakter dapat diartikan sebagai suatu usaha yang disengaja untuk membantu seseorang sehingga ia dapat memahami, memperhatikan, dan melakukan nilai-nilai etika yang inti (Lickona, 2005: 63).

Sintesa dari berbagai pengertian tersebut, karakter adalah sifat yang menjadi ciri khas yang dimiliki seseorang untuk melakukan tindakan etis dalam hidup bermasyarakat. Secara sederhana, pendidikan karakter dapat didefinisikan sebagai segala usaha yang dapat dilakukan untuk mempengaruhi karakter pembelajar, sehingga ketika dewasa siswa mampu menunjukkan sikap dan perilaku luhur dalam hidup bermasyarakat, berbangsa dan bernegara. 
Berdasarkan pada kajian teroi tersebut, maka dapat disimpulkan bahwa modul perkuliahan bahasa Indonesia bermuatan nilai karakter kebangsaan adalah bahan ajar yang bersifat sistematis dan praktis, diperuntukkan bagi mahasiswa PGSD dan di dalamnya memuat nilai-nilai karakter kebangsaan sesuai kurikulum 2013. Modul perkuliahan bahasa Indonesia bermuatan nilai karakter kebangsaan disusun untuk mempermudah mahasiswa menguasai materi perkuliahan bahasa Indonesia yang sesuai dengan implementasi kurikulum saat ini. Modul merupakan sarana belajar yang memiliki sifat praktis dan sistematis (Anwar, 2010:96), sehingga mudah digunakan mahasiswa baik secara terbimbing maupun secara mandiri untuk menguasai isi materi di dalam modul.

Banyak temuan-temuan para peneliti terdahulu yang membuktikan bahwa penggunaan modul sebagai sarana pembelajaran memiliki nilai efektivitas yang tinggi, seperti penelitian yang dilakukan oleh:

Akmalia, dalam penelitian yang berjudul "Pengembangan Modul IPA Terpadu Berkarakter Tema Pemanasan Global untuk Siswa SMP/MTs" yang dimuat dalam Unnes Science Education Journal, menunjukkan bahwa modul yang dikembangkan layak dan efektif digunakan untuk pembelajaran di SMP/MTs kelas VII (Akmalia, 2013:73);

Anton Ginanjar, melalui penelitian yang berjudul "Pengembangan Media Pembelajaran Modul Interaktif Mata Kuliah Pemindahan Tanah Mekanik" membuktikan bahwa tanggapan dan minat mahasiswa dalam menggunakan modul interaktif pemindahan tanah mekanik ini termasuk dalam kategori "baik" (Ginanjar, 2010: 62).

Efriana, dalam penelitiannya yang berjudul "Pengembangan modul IPA Terpadu Berkarakter pada Tema Pengelolaan
Lingkungan untuk Siswa Kelas VII SMP" yang dimuat dalam Unnes Science Education Juornal, modul terbukti efektif digunakan dalam pembelajaran siswa kelas VII SMP Negeri 2 Kajen (Efriana, 2013:84);

Ika Muryani, dalam penelitian yang berjudul "Pengembangan Modul Pembelajaran Biologi Berbasis Sains Teknologi Masyarakat (STM) untuk Siswa Kelas X SMA/MA". Hasil penelitiannya menunjukkan bahwa berdasarkan hasil analisis reviewer kualitas modul tersebut sangat baik (SB) dengan presentase $85,88 \%$ dan presentase berdasarkan respon siswa 90,44 \% (Muryani, 2014: 78);

Nisa Ul Istiqomah dalam penelitiannya yang berjudul "Pengembangan Modul Matematika Materi Ruang Dimensi Tiga Berbasis Pendidikan Karakter dengan Pendekatan Kontekstual Untuk SMA Kelas X" membuktikan bahwa rata-rata skor aspek kelayakan isi, kelayakan bahasa, kelayakan penyajian, penilaian kontekstual dan penilaian karakter dengan kriteria "Sangat Baik" serta kelayakan kegrafikaan dengan kriteria "Baik" (Istiqomah, 2012: 94); dan

Parmin, dalam penelitiannya yang berjudul "Pengembangan Modul Mata Kuliah Strategi Belajar Mengajar IPA Berbasis Hasil Penelitian Pembelajaran" yang dimuat dalam Jurnal Pendidikan IPA Indonesia menunjukkan bahwa modul yang dikembangkan terbukti efektif berdasarkan hasil perolehan nilai mahasiswa (Parmin, 2012: 83).

Berdasarkan beberapa penelitian terdahulu tersebut maka dapat disintesiskan bahwa penggunaan modul terbukti sangat membatu meningkatkan prestasi siswa/mahasiswa pada proses pembelajaran. Adapun pada penelitian ini, peneliti berupaya meningkatkan pemahaman nilai-nilai karakter 
kebangsaan mahasiswa melalui penggunaan modul bermatan karakter kebangsaan.

\section{METODE PENELITIAN}

Penelitian yang dilaksanakan tergolong penelitian pengembangan atau Research and Development (R\&D). Produk yang dikembangkan adalah bahan ajar berupa modul perkuliahan mata kuliah bahasa Indonesia bermuatan nilai karakter kebangsaan untuk mahasiswa PGSD. Model pengembangan modul perkuliahan dalam penelitian ini mengacu pada model Thiagarajan dalam (Rohmad, 2012: 63) yang terdiri dari empat tahap pengembangan yang sering diistilahkan 4-D yaitu pendefinisian (define), perancangan (design), pengembangan (develop), dan penyebaran (dessiminate). Namun karena penelitian ini dilakukan hanya satu tahun, maka pengembangan yang dilakukan hanya sampai pada tahap ketiga (develop) saja.

Lingkup penelitian ini tergolong dalam penelitian pendidikan. Objek penelitian pengembangan ini adalah modul perkuliahan bahasa Indonesia bermuatan nilai karakter kebangsaan, sementara itu subjek penelitian ini yaitu dosen dan mahasiswa PGSD UM Magelang. Tempat penelitian berada di Kampus 1 Universitas Muhammadiyah Magelang. Variabel penelitian ini dapat dipilah menjadi dua yakni yang pertama adalah modul perkuliahan yang dikembangkan sedangkan variabel kedua yaitu efektivitas perkuliahan dosen dan mahasiswa. Analisis data yang digunakan yakni menghitung hasil respon dosen dan mahasiswa. Keberhasilan penelitian terletak pada sejauh mana modul yang dikembangkan dapat membantu dosen dan mahasiswa dalam melaksanakan aktivitas perkuliahan. Kriteria yang digunakan terdiri atas lima level meliputi: (1) tidak membantu; (2) kurang membantu; (3) cukup membantu; (4) membantu; dan (5) sangat membantu.

\section{HASIL DAN PEMBAHASAN}

Hasil yang dicapai dari pelaksanaan penelitian terbagi atas beberapa bagian sebagai berikut.

Tahap A. (define) ini merupakan tahap awal yang dilakukan dalam penelitian pengembangan modul Bahasa Indonesia bermuatan nilai karakter kebangsaan. Tahap ini dijadikan dasar melangkah pada tahap berikutnya yakni tahap B. (design), dan tahap C. (develop). Tahap define ini merupakan tahapan menganalisis kebutuhan modul seperti apa yang dibutuhkan mahasiswa PGSD. Pada tahap ini terdapat empat analisis meliputi: analisis awal akhir, analisis mahasiswa, analisis materi, dan analisis tugas, serta perumusan tujuan perkuliahan khusus. Rumusan analisis pada tahap ini dapat dijelaskan sebagai berikut.

Analisis mengenai kondisi awal dan prediksi kondisi akhir perlu dilakukan mengingat pengembangan modul ini dimaksudkan untuk membekali pemahaman mahasiswa mengenai karakter kebangsaan, kondisi awal dapat digambarkan bahwa mahasiswa belum sepenuhnya memahami karakter kebangsaan yang harus ditanamkan pada diri pribadi dan diteladankan kepada orang lain. Mahasiswa PGSD merupakan mahasiswa yang sedang menempuh pendidikan untuk mendapatkan bekal kompetensi guru sekolah dasar. Jumlah mahasiswa yang hendak dijadikan subjek penelitian sebanyak 280 orang dengan latar belakang yang beragam. Perlunya dilakukan analisis mahasiswa ialah untuk menjamin produk pengembangan modul yang dilakukan mampu menjawab kebutuhan mahasiswa 
secara tepat, mudah diterima, dan memiliki manfaat yang nyata. Kondisi mahasiswa PGSD yang menjadi subjek penelitian pengembangan ini dilihat dari segi jenis kelamin, presentase mahasiswa berkisar antara 10\% mahasiswa laki-laki dan $90 \%$ mahasiswa perempuan. Sementara itu dari latar belakang pendidikan mahasiswa yang berlatar belakang SMA IPA 45\%, SMA IPS $40 \%$, dan lainnya $15 \%$. Latar belakang keluarga mahasiswa pun beragam misalnya orang tuanya berprofesi sebagai pegawai negeri, swasta, buruh, sopir, dan sebagainya. Analisis mengenai kondisi mahasiswa ini dijadikan pertimbangan dalam menyusun modul bermuatan nilai karakter, yakni bagaimana upaya yang dapat dilakukan untuk menginternalisasi nilai-nilai karakter kebangsaan pada mahasiswa PGSD tersebut.

Materi perkuliahan yang hendak disusun senantiasa mengacu pada kurikulum skala nasional. Beberapa sumber yang dapat dirujuk di antaranya: buku modul yang telah disusun beberapa pakar dan modul yang telah digunakan beberapa dosen baik perguruan tinggi negeri maupun swasta. Beberapa aspek yang dikaji pada modul yang hendak disusun di antaranya: (1) pengertian atau hakikat bahasa dan sastra; (2) karakteristik anak usia SD (3) kompetensi kebahasaan siswa SD (4) strategi pembelajaran bahasa di SD; dan (5) inovasi pembelajaran bahasa di SD.

Tahap B (design), tujuan tahap ini yaitu untuk merancang prototype modul perkuliahan yang terdiri atas 4 tahap, yaitu: (1) tahap penyusunan; (2) tahap pemilihan media; (3) tahap pemilihan format; dan (4) tahap rancangan awal (design awal). Dalam hal ini rancangan awal yang dibuat adalah modul perkuliahan, lembar validasi modul perkuliahan, angket respon dosen dan respon mahasiswa terhadap modul perkuliahan bermuatan nilai karakter kebangsaan. Selanjutnya rancangan awal ini disebut Draft I. Proses penyusunan draft I modul perkuliahan ini dilakukan setelah melalui berbagai pertimbangan seperti yang telah dijelaskan di muka. Pada tahap design ini pula disusun instrumen yang digunakan untuk menguji kelayakan modul. Beberapa aspek yang dinilai pada instrumen penelitian di antaranya: (1) kemenarikan modul perkuliahan; (2) penggunaan modul perkuliahan dapat membantu dosen dalam menyampaikan materi perkuliahan; (3) kepraktisan dalam penggunaan modul perkuliahan; (4) kemanfaatan modul dalam proses perkuliahan; (5) penyampaian materi dengan modul perkuliahan lebih efektif dan efisien sesuai waktu yang disediakan; (6) modul perkuliahan dapat digunakan berulang kali sesuai kebutuhan; (7) menginspirasi dosen/mahasiswa untuk lebih kreatif dalam kegiatan perkuliahan; (8) kemudahan dosen/mahasiswa dalam penggunaan modul perkuliahan; (9) keterbacaan bahasa dalam modul perkuliahan; dan (10) kejelasan penyajian materi dan latihan soal dalam modul perkuliahan.

Tahap C (Develop,) tujuan tahap ini adalah untuk menghasilkan draft modul perkuliahan yang telah direvisi berdasarkan masukan validator dan data yang diperoleh dari uji coba. Pada tahap ini terdapat dua langkah kegiatan, yaitu: validasi modul perkuliahan dan uji coba modul perkuliahan. Hasil validasi tampak pada tabel. 1 .

Tabel tersebut menunjukkan bahwa masih banyak aspek yang perlu direvisi, di antaranya: mempermudah penyampaian materi, kepraktisan, ketepatan waktu, serta kejelasan materi dan soal. 
Tabel 1. Hasil Validasi draft I

\begin{tabular}{llc}
\hline No & Aspek yang Diamati & $\begin{array}{c}\text { Presentase } \\
\text { Tingkat } \\
\text { Kesesuaian } \\
(\mathbf{0}-\mathbf{1 0 0 \%})\end{array}$ \\
\hline 1 & Kemenarikan modul & $67 \%$ \\
2 & Mempermudah & $57 \%$ \\
& penyampaian materi & $55 \%$ \\
3 & Kepraktisan & $60 \%$ \\
4 & Kemanfaatan & $40 \%$ \\
5 & Ketepatan waktu & $70 \%$ \\
6 & Tingkat kegunaan & $65 \%$ \\
7 & kembali & $62 \%$ \\
8 & Inspiratif & \\
& Memudahkan & $70 \%$ \\
9 & mahasiswa & $55 \%$ \\
10 & Keterbacaan & \\
\hline
\end{tabular}

Berdasarkan data hasil validasi ahli dan standar kriteria kevalidan di atas, maka pada draft 1 masih terdapat empat aspek yang perlu diperbaiki di antaranya:

a. Membantu mempermudah penyampaian materi.

Peranan modul sebagai sarana penyampaian materi sangat berpengaruh terhadap pemahaman mahasiswa dalam menguasai perkuliahan. Demikian pula modul yang hendak dikembangkan ini harus memenuhi kriteria yang baik dalam membantu mempermudah penyampaian materi. Sesuai saran validator pada instrumen validasi ahli, hendaknya modul yang dikembangkan ini lebih diperjelas lagi masing-masing subkompetensi beserta bagian-bagian pendukungnya. Berdasarkan saran itu, peneliti segera melakukan perbaikan melalui proses mengedit hingga tersusun subkompetensi yang teratur dan mudah dipahami.

b. Kepraktisan modul
Dari segi kepraktisan, modul yang sedang dikembangkan ini dinilai masih kurang. Hal ini tampak pada isi modul yang masih perlu dirapikan dan terlalu banyak istilah yang kurang mendukung. Berdasarkan saran tersebut, peneliti segera melakukan perbaikan dan penyempurnaan agar dihasilkan modul yang praktis digunakan baik oleh dosen maupun mahasiswa. Beberapa perbaikan tersebut di antaranya: (1) melakukan edit cover; (2) mengemas kembali isi modul lebih terinci; (3) mengatur tata letak paragraf, tabel, grafik, dan gambar; dan (4) memperbaiki lay out di bagian akhir modul.

c. Kesesuaian alokasi waktu masing-masing subpokok bahasan

Kesesuaian antara waktu dengan isi subpokok bahasan pada modul yang disusun masih dinilai kurang. Ini dapat dilihat dari kurang seragamnya masingmasing subkompetensi dengan alokasi waktu yang tersedia. Masih terdapat subkompetensi yang luas namun dialokasikan dengan waktu yang sedikit dan ada pula subkompetensi yang sempit namun dengan alokasi waktu yang terlalu luas. Berdasarkan saran validator tersebut, peneliti segera melakukan penyempurnaan dari segi alokasi waktu. Penyusunan kembali subkompetensi/pokok bahasan dengan alokasi waktu juga diupayakan agar seimbang.

d. Kejelasan materi dan daftar soal

Kejelasan materi dan daftar soal pada modul yang dikembangkan masih dinilai kurang oleh validator. Hal ini dibuktikan dengan masih ditemukannya istilah yang kurang sesuai dengan isi materi modul. Selain kejelasan materi, juga daftar soal 
dinilai kurang jelas dan perlu disesuaikan. Kejelasan soal ini seharusnya dapat dipahami mahasiswa dan berkaitan langsung dengan materi yang dibahas. Berdasarkan saran dari validator tersebut, peneliti segera melakukan perbaikan dengan menyusun kembali uraian materi secara lebih jelas dan lugas serta menyusun butir soal yang mudah dipahami dan berkaitan langsung dengan uraian materi yang dibahas sebelumnya.

Sementara itu aspek yang sudah cukup baik dan tidak memerlukan revisi di antaranya: kemenarikan modul, kemanfaatan, tingkat kegunaan kembali, inspiratif, memudahlan mahasiswa, dan keterbacaan. Hasil validasi ahli ini digunakan sebagai acuan untuk melangkah pada tahap berikutnya yakni revisi atau penyempurnaan modul agar menghasilkan produk yang lebih baik lagi.

Langkah berikutnya adalah penyusunan draft II. Hal ini dilakukan setelah mendapatkan masukan dari validator. Melalui perbaikan ini diharapkan dapat menghasilkan modul yang layak untuk digunakan bagi mahasiswa PGSD. Draft II yang telah tersusun selanjutnya diuji coba dengan cara digunakan untuk mengisi materi perkuliahan. Kegiatan perkuliahan dengan menggunakan draft II modul hasil pengembangan ini dipantau secara berkala dan dianalisis hasilnya di akhir penggunaan modul. Uji coba dilaksanakan pada dosen pengampu mata kuliah Bahasa Indonesia dan mahasiswa PGSD semester 2 FKIP UM Magelang dengan jumlah mahasiswa sebanyak 280 orang.

Pelaksanaan uji coba draft II
menghasilkan beberapa data yang menunjukkan bahwa modul yang digunakan telah memenuhi unsur kelayakan dan membantu proses perkuliahan. Hal ini dibuktikan dengan adanya respon dosen dan mahasiswa setelah menggunakan modul merasa bahwa modul perkuliahan Bahasa Indonesia bermuatan nilai karakter kebangsaan telah membantu mahasiswa memahami, baik isi materi maupun nilai-nilai karakter kebangsaan yang harus dijiwai dan diteladankan kepada murid SD kelak. Dalam pelaksanaannya, uji coba draft II membutuhkkan peranan dosen dan mahasiswa. Kedua unsur tersebut merupakan pelaku utama dalam proses perkuliahan. Uji coba dilakukan secara bertahap. Pada setiap tahapan, dosen memberikan subpokok bahasan dengan mengaitkan nilai karakter kebangsaan dalam proses perkuliahan. Adapun nilai karakter kebangsaan yang diaplikasikan adalah sebanyak delapan belas karakter seperti telah dijelaskan di muka. Hasil uji coba dan validasi draft II selanjutnya digunakan sebagai acuan untuk menyusun naskah final modul perkuliahan Bahasa Indonesia yang bermuatan nilai karakter kebangsaan.

Tabel 2. Hasil Validasi draft II

\begin{tabular}{llr}
\hline No & Aspek yang Diamati & $\begin{array}{c}\text { Presentase } \\
\text { Tingkat } \\
\text { Kesesuaian } \\
(\mathbf{0}-\mathbf{1 0 0 \% )}\end{array}$ \\
\hline 1 & Kemenarikan modul & $84 \%$ \\
2 & Mempermudah & $82 \%$ \\
& penyampaian materi & \\
3 & Kepraktisan & $90 \%$ \\
4 & Kemanfaatan & $86 \%$ \\
5 & Ketepatan waktu & $80 \%$ \\
6 & Tingkat kegunaan kembali & $88 \%$ \\
7 & Inspiratif & $87 \%$ \\
8 & Memudahkan mahasiswa & $80 \%$ \\
9 & Keterbacaan & $93 \%$ \\
10 & Kejelasan materi dan soal & $90 \%$ \\
\hline
\end{tabular}

Naskah final ini selanjutnya dapat digunakan sebagai salah satu referensi 
perkuliahan Bahasa Indonesia pada program studi Pendidikan Guru Sekolah Dasar (PGSD) Adapun hasil validasi dan uji coba draft II tampak pada tabel. 2 .

Berdasarkan dua tabel pada bagian hasil penelitian, maka dapat kita cermati bahwa proses pengembangan dan penyempurnaan modul berkorelasi positif dengan peningkatan kualitas modul. Ini didasarkan pada hasil penilaian validator terhadap kualitas modul dari segi kemenarikan, hingga kejelasan materi dan soal. Peningkatan yang sangat signifikan tampak pada aspek mempermudah penyampaian, unsur kepraktisan, ketepatan waktu, dan kejelasan materi serta soal.

\section{SIMPULAN}

Mengacu pada kriteria keberhasilan penelitian yang telah dibahas pada bagian muka, serta melihat hasil validasi ahli dan respon dosen-mahasiswa, maka modul perkuliahan Bahasa Indonesia bermuatan nilai karakter kebangsaan yang disusun dan dikembangkan pada penelitian ini telah dapat dikatakan layak untuk digunakan.

Keterbatasan penelitian ini di antaranya adalah (1) merupakan penelitian tahap pemula; (2) durasi pengembangannya hanya satu tahun sehingga kurang maksimal; dan (3) lingkup penelitian masih sempit, yakni hanya pada satu instansi. Pada peneliti berikutnya diharapkan dapat melakukan penelitian serupa pada skala yang lebih luas.

\section{DAFTAR PUSTAKA}

Akmalia. (2013). "Pengembangan Modul IPA terpadu Berkarakter Tema Pemanasan Global untuk Siswa SMP/MTs". Unnes Science Education Journal, Vol 2 (No 1), 203-208.

Anwar, I. (2010). Pengembangan Bahan Ajar. Bandung, Jawa Barat, Indonesia: Direktori UPI.

Baswedan, A. (2014, 12 4). Surat Edaran Mendikbud Nomor: 179324/MPK/KR/2014.

Depdiknas. (2006). Teknik Penyusunan Modul. Jakarta: Departemen Pendidikan Nasional.

Efriana. (2013). "Pengembangan Modul IPA Terpadu Berkarakter pada Tema Pengelolaan Lingkungan untuk Siswa Kelas VII SMP." Unnes Science Education Journal , Vol 2 (No 2), Hal 269-273.

Ginanjar, A. (2010). Pengembangan Media Pembelajaran Modul Interaktif Mata Kuliah Pemindahan Tanah Mekanik. Universitas Sebelas Maret, FKIP. Surakarta: UNS Press.

Istiqomah, N. U. (2012). Pengembangan Modul Matematika Materi Ruang Dimensi Tiga Berbasis Pendidikan Karakter dengan Pendekatan Kontekstual Untuk SMA Kelas X. Universitas Negeri Yogyakarta, FMIPA. Yogyakarta: UNY Press.

Kertajaya, H. (2010). On Brand. Bandung: Mizan Pustaka. 
Lickona. (2005). Smart \& Good High Schools: Integrating Excellence and Ethics for Success in School, Work, and Beyond. New York: The Character Education Partnership.

Muryani, I. (2014). Pengembangan Modul Pembelajaran Biologi Berbasis Sains Teknologi Masyarakat (STM) untuk Siswa Kelas X SMA/MA. Universitas Negeri Yogyakarta, FMIPA. Yogyakarta: UNY Press.

Parmin. (2012). "Pengembangan Modul Mata Kuliah Strategi Belajar Mengajar IPA Berbasis Hasil Penelitian Pembelajaran." Jurnal Pendidikan IPA Indonesia , Vol 1 (No 1), hal 8-15.

Rohmad. (2012). "Desain Model Pengembangan Perangkat Pembelajaran." Kreano, Vol 3 (No 1), Hal 59-72.

Rusimamto. (2013). "Pengembangan Modul Ajar Mata Kuliah Fisika II untuk Model Pembelajaran Kooperatif sebagai Upaya Meningkatkan Kualitas Hasil Pembelajaran di Jurusan Teknik Elektro FT Unesa." Seminar Nasional Pendidikan Teknik Elektronika (p. 901). Surabaya: Unesa Press.

Suryaman, M. (2012). Metodologi Pembelajaran Bahasa. Yogyakarta: UNY Press.

Suyanto. (2010). Aktualisasi Pendidikan Karakter . Jakarta: Direktorat Jenderal Manajemen Pendidikan Dasar Menengah .

Winkel. (2009). Psikologi Pengajaran Yogyakarta. Yogyakarta: Media Abadi. 